\title{
Genetic Evaluation and Screening of Diverse Wheat Genotypes for Spot Blotch Resistance
}

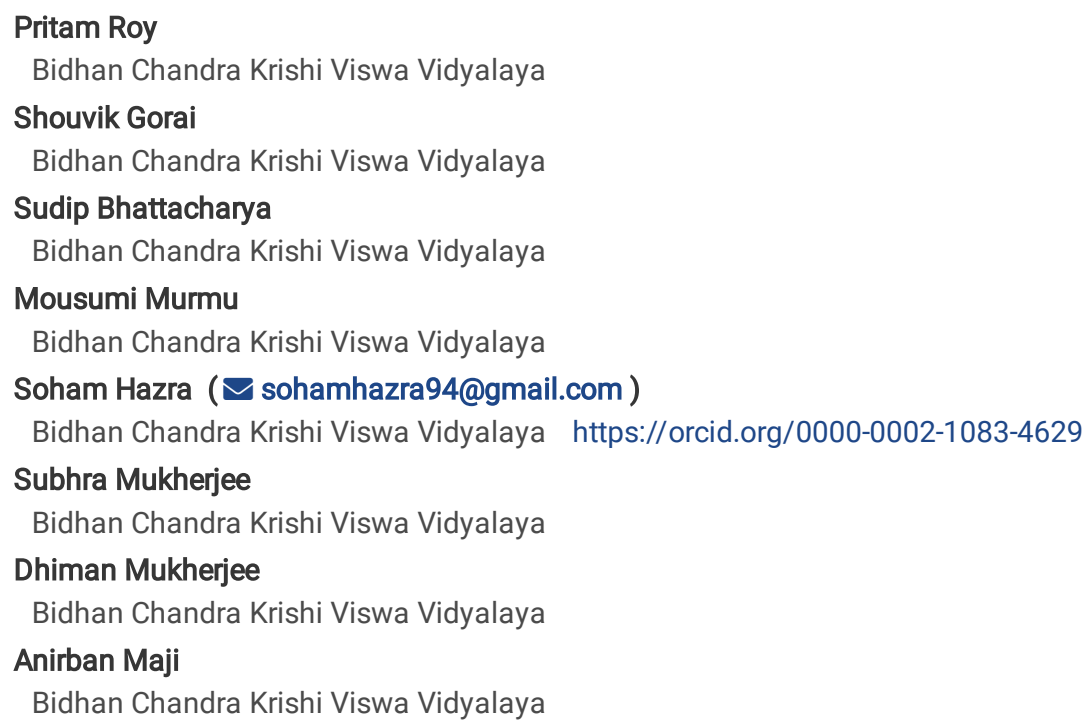

\section{Research Article}

Keywords: Wheat, diversity, spot blotch, AUDPC, screening, resistance breeding

Posted Date: September 20th, 2021

DOI: https://doi.org/10.21203/rs.3.rs-790115/v1

License: (c) (i) This work is licensed under a Creative Commons Attribution 4.0 International License. Read Full License 


\section{Abstract}

Production of wheat (Triticum aestivum L.) the main food source of South Asian countries including India faces several constraints including spot blotch caused by Bipolaris sorokiniana resulting in yield loss of $25-43 \%$ depending upon the stage of infection. Fifty genotypes were evaluated for nine quantitative characters and area under disease progress curve (AUDPC) to identify superior genotype with spot blotch resistance. High heritability coupled with moderate to high genetic advance as percent of mean was registered for grains per spike, tillers per square meter, days to $50 \%$ heading and days to $50 \%$ flowering indicating the characters to be governed by additive genes. Correlation and path coefficient analysis favored days to $50 \%$ heading, days to $50 \%$ flowering and grains per spike since they had significant positive correlation with yield and simultaneous negative correlation with AUDPC and also conferring highest positive direct effect towards yield. Multiple linear regression (MLR) analysis indicated days to $50 \%$ heading to be most sensitive with negative influence on AUDPC. $D^{2}$ analysis grouped the 50 genotypes into 10 clusters suggesting presence of diversity among the genotypes. Frequency distribution of AUDPC among the genotypes showed more or less normal distribution of the character. Low AUDPC score with acceptable level of yield performance were recorded for the genotypes 29882, 29610, 29473, 29940, 29477, 29748 and 30081. Identification of high yielding and less susceptible genotypes for spot blotch disease in the present investigation offered an opportunity for wheat improvement through selective breeding.

\section{Introduction}

Bread wheat (Triticum aestivum L.) one of the oldest cereal crop is regarded as the 'King of Cereals' since it shares a large area under production, high productivity and holds a prominent position in the international food grain trade (Hazra et al. 2019a). It is the main food source of South Asian countries (Singh et al. 2016) and in India it is the principal cereal crop next to rice (Kumari et al. 2020). The overall production of wheat in India has gone up tremendously from 12.26 million tonnes in 1964-65 to 103.6 million tonnes in 2018-19. Recently, an estimate of United States Department of Agriculture (USDA) states that India is expected to touch the new level of wheat production about 107.0 million tonnes in 2020-21 (USDA 2021).

Production of bread wheat in South East Asian countries including India still faces various constrains like raising temperature, unexpected hailstorms, erratic and unusual precipitation during February-March (Duveiller 2004), exposing the crop to several diseases and pests including spot blotch or foliar blight of wheat. West Bengal is categorized as a hotspot for the disease because of its mild and short winter, humid climate and late sowing due to delay in harvesting of kharif rice and sometimes excessive soil moisture after rice harvest. Warm and humid climate of this region aggravates the disease which seriously hampers the production of intensive cropping system (Singh et al. 2016). The yield loss may range from 25$43 \%$ depending upon the stage of infection and the national yield loss is recorded to be around 18-22\% (Acharya et al. 2011).

Spot blotch is caused by a hemi biotrophic fungal pathogen Bipolaris sorokiniana (Sacc.) Shoem syn. Drechslera sorokiniana (Sacc.) Subrm and Jain (syn. Helminthosporium sativum) and its teleomorph is Cochliobolus sativus (Singh et al. 2016). Typical symptoms of the spot blotch disease appear on the leaves, sheath, nodes and glumes with brown lesions of oval to oblong or elliptical in shape measuring 5 to $10 \mathrm{~mm}$ long and 3 to 5 $\mathrm{mm}$ wide (Gupta et al. 2018). Other symptoms include darkening of the sub crown region, dark brown lesions on culm, coleoptile, crowns and roots. This pathogen first attacks the older leaves at the base of the plant and then progresses upward (Joshi et al. 2002). Lesions on leaves may start from few mm and later it turns into dark brown spots and can extend up to 1-2 cm (Chand et al. 2002). As the disease progresses, the lesions get scattered throughout the leaves and subsequently their size increase to coalesce with each other to form large necrotic spots which result in loss chlorophyll that causes reduction in photosynthetic area of the leaf (Gupta et al. 2018). Sometimes yellowing can be seen due to toxin production from the lesion (Chowdhury et al. 2013). In its severe form the fungal pathogen attacks the spikes forming dark brown to black discolouration around the germinating point of the seed known as "Black Point" (Gupta et al. 2018).

The genetic base of cultivated wheat genotypes has become narrow due to continuous inbreeding (Rehman et al. 2018) and the present agricultural scenario has led to rapid decline in both inter and intra varietal variability as a result of continuous breeding of the elite genotypes. Complete resistance in bread wheat genotypes against spot blotch or foliar blight is still lacking, although low to high levels of resistance have been reported (Rosyara et al. 2007; Singh et al. 2020). In high yielding varieties of wheat resistance to spot blotch is poor and requires rigorous investigation to improve the resistance along with good yield (Joshi et al. 2007; Meena et al. 2014). The existing genetic variability can be exploited by intercrossing among diverse genotypes to isolate superior transgressive seggregants (Baranwal et al. 2012; Shah et al. 2020). Identification of superior diverse genotypes with desirable traits and their consequent use in breeding program and establishment of successful selection criteria can be helpful for successful varietal improvement (Hazra et al. 2019b).

The present investigation has been aimed to assess the interrelation between the disease score and other important agro-morphological traits of fifty diverse wheat genotypes grown naturally under a hotspot region for the disease in India for formulating an effective selection criterion for spot blotch resistance wheat breeding.

\section{Materials And Methods}

\section{Experimental material}


Fifty bread wheat genotypes (Table 1) collected from International Center for Agricultural Research in Dry Areas (ICARDA), Aleppo, Syria and AICRPIndian Institute of Wheat and Barley Research (ICAR-IIWBR), Karnal, India was used in the present study to screen for the resistance to spot blotch disease and other agronomic traits. Out of the fifty genotypes, HD2967, HD3086 and DBW107 were used as yield check as suggested by Gupta et al. (2017) while Sonalika, vulnerable to spot blotch, was used as a susceptible check variety for spot blotch disease screening according to Turan et al. (2017). 
Table 1

Fifty wheat genotypes used in the present investigation

\begin{tabular}{|c|c|c|c|}
\hline $\begin{array}{l}\text { Sl. } \\
\text { No. }\end{array}$ & $\begin{array}{l}\text { Code no. of } \\
\text { genotypes }\end{array}$ & Parentage & Source \\
\hline 1 & TERBOL & TERBOL & $\begin{array}{l}\text { International Center for Agricultural Research } \\
\text { in Dry Areas (ICARDA) }\end{array}$ \\
\hline 2 & ATLAS & ATLAS & $\begin{array}{l}\text { International Center for Agricultural Research } \\
\text { in Dry Areas (ICARDA) }\end{array}$ \\
\hline 3 & TESFA & TESFA & $\begin{array}{l}\text { International Center for Agricultural Research } \\
\text { in Dry Areas (ICARDA) }\end{array}$ \\
\hline 4. & 30140 & ABU-REYAA-1/LEITH-1 & $\begin{array}{l}\text { International Center for Agricultural Research } \\
\text { in Dry Areas (ICARDA) }\end{array}$ \\
\hline 5. & 30081 & ABUZIG-10//2*PFAU/MILAN & $\begin{array}{l}\text { International Center for Agricultural Research } \\
\text { in Dry Areas (ICARDA) }\end{array}$ \\
\hline 6. & 29882 & ALMAZ-19/ETBW 4919/3/NING MAI 9558//CHIL/CHUM18 & $\begin{array}{l}\text { International Center for Agricultural Research } \\
\text { in Dry Areas (ICARDA) }\end{array}$ \\
\hline 7. & 30053 & ANBER-6//WORRAKATTA/PASTOR & $\begin{array}{l}\text { International Center for Agricultural Research } \\
\text { in Dry Areas (ICARDA) }\end{array}$ \\
\hline 8. & 29889 & ASEEL-1//MILAN/PASTOR/3/SHAMISS-3 & $\begin{array}{l}\text { International Center for Agricultural Research } \\
\text { in Dry Areas (ICARDA) }\end{array}$ \\
\hline 9. & 29760 & ATTILA*2/AMAD//ENKOY/3/PFAU/MILAN & $\begin{array}{l}\text { International Center for Agricultural Research } \\
\text { in Dry Areas (ICARDA) }\end{array}$ \\
\hline 10. & Sonalika (C) & SONALIKA (C) & $\begin{array}{l}\text { AICRP-Indian Institute of Wheat and Barley } \\
\text { Research (ICAR-IIWBR) }\end{array}$ \\
\hline 11. & 29761 & ATTILA*2/AMAD//ENKOY/3/PFAU/MILAN & $\begin{array}{l}\text { International Center for Agricultural Research } \\
\text { in Dry Areas (ICARDA) }\end{array}$ \\
\hline 12. & 29872 & $\begin{array}{l}\text { ATTILA-1/NS732/HER//PARUS/PASTOR/3/TEMPORALERAM } \\
87 * 2 / K O N K\end{array}$ & $\begin{array}{l}\text { International Center for Agricultural Research } \\
\text { in Dry Areas (ICARDA) }\end{array}$ \\
\hline 13. & 29610 & BACANORA T 88/RUTH-2 & $\begin{array}{l}\text { International Center for Agricultural Research } \\
\text { in Dry Areas (ICARDA) }\end{array}$ \\
\hline 14. & 29821 & BACANORA T 88/RUTH-2//PFAU/MILAN & $\begin{array}{l}\text { International Center for Agricultural Research } \\
\text { in Dry Areas (ICARDA) }\end{array}$ \\
\hline 15. & 29690 & BAOBAB-1//MILAN/PASTOR & $\begin{array}{l}\text { International Center for Agricultural Research } \\
\text { in Dry Areas (ICARDA) }\end{array}$ \\
\hline 16. & 29672 & CHAM-6/SHUHA-14/5/KAUZ/3/MYNA/VUL//BUC/FLK/4/MILAN & $\begin{array}{l}\text { International Center for Agricultural Research } \\
\text { in Dry Areas (ICARDA) }\end{array}$ \\
\hline 17. & 29748 & CHAM-8/FLAG-3//MILAN/PASTOR & $\begin{array}{l}\text { International Center for Agricultural Research } \\
\text { in Dry Areas (ICARDA) }\end{array}$ \\
\hline 18. & 29612 & CHAM-8/RUTH-3 & $\begin{array}{l}\text { International Center for Agricultural Research } \\
\text { in Dry Areas (ICARDA) }\end{array}$ \\
\hline 19. & 29824 & CHAMRAN/4/OPATA/BOW//BAU/3/OPATA/BOW/5/SAMIRA-9 & $\begin{array}{l}\text { International Center for Agricultural Research } \\
\text { in Dry Areas (ICARDA) }\end{array}$ \\
\hline 20. & 29506 & CROC-1/AE.SQUARROSA (205)//MILAN/KAUZ/3/MILAN/PASTOR & $\begin{array}{l}\text { International Center for Agricultural Research } \\
\text { in Dry Areas (ICARDA) }\end{array}$ \\
\hline 21. & 29509 & CROC-1/AE.SQUARROSA (205)//MILAN/KAUZ/3/MILAN/PASTOR & $\begin{array}{l}\text { International Center for Agricultural Research } \\
\text { in Dry Areas (ICARDA) }\end{array}$ \\
\hline 22. & HD 2967 (C) & HD2967 (C) & $\begin{array}{l}\text { AICRP-Indian Institute of Wheat and Barley } \\
\text { Research (ICAR-IIWBR) }\end{array}$ \\
\hline 23. & 29865 & $\begin{array}{l}\text { DAJAJ-5/4/CHEN/AEGILOPSSQUARROSA } \\
\text { (TAUS)//BCN/3/KAUZ/5/WBLL1*2/KIRITATI }\end{array}$ & $\begin{array}{l}\text { International Center for Agricultural Research } \\
\text { in Dry Areas (ICARDA) }\end{array}$ \\
\hline 24. & 29522 & DURRA-2/TAZA-2 & $\begin{array}{l}\text { International Center for Agricultural Research } \\
\text { in Dry Areas (ICARDA) }\end{array}$ \\
\hline 25. & 30001 & FAYEQ-2/3/NESMA*2/14 - 2//2*SAFI-3 & $\begin{array}{l}\text { International Center for Agricultural Research } \\
\text { in Dry Areas (ICARDA) }\end{array}$ \\
\hline
\end{tabular}

The genotypes designated as (C) has been used as check. 


\begin{tabular}{|c|c|c|c|}
\hline $\begin{array}{l}\text { Sl. } \\
\text { No. }\end{array}$ & $\begin{array}{l}\text { Code no. of } \\
\text { genotypes }\end{array}$ & Parentage & Source \\
\hline 26. & HD3086 (C) & HD3086 (C) & $\begin{array}{l}\text { AICRP-Indian Institute of Wheat and Barley } \\
\text { Research (ICAR-IIWBR) }\end{array}$ \\
\hline 27. & 29784 & GEMMEIZA-10/SHAMISS-3 & $\begin{array}{l}\text { International Center for Agricultural Research } \\
\text { in Dry Areas (ICARDA) }\end{array}$ \\
\hline 28. & 29782 & $\begin{array}{l}\text { HUBARA-1//ACHTAR/INRA1764/7/CHAM- } \\
\text { 8/6/SAKER'S'/5/RBS/ANZA/3/KVZ/HYS//YMH/TOB/4/BOW'S' }\end{array}$ & $\begin{array}{l}\text { International Center for Agricultural Research } \\
\text { in Dry Areas (ICARDA) }\end{array}$ \\
\hline 29. & 29641 & HUBARA-1/5/KAUZ/3/MYNA/VUL//BUC/FLK/4/MILAN & $\begin{array}{l}\text { International Center for Agricultural Research } \\
\text { in Dry Areas (ICARDA) }\end{array}$ \\
\hline 30. & 29502 & INQALAB91*2/TUKURU//MILAN/PASTOR & $\begin{array}{l}\text { International Center for Agricultural Research } \\
\text { in Dry Areas (ICARDA) }\end{array}$ \\
\hline 31. & 29703 & JAWAHIR-6/ETBW 4921 & $\begin{array}{l}\text { International Center for Agricultural Research } \\
\text { in Dry Areas (ICARDA) }\end{array}$ \\
\hline 32. & 29490 & KATILA-13//PFAU/MILAN & $\begin{array}{l}\text { International Center for Agricultural Research } \\
\text { in Dry Areas (ICARDA) }\end{array}$ \\
\hline 33. & 29473 & PBW343*2/KUKUN//ANBER-9 & $\begin{array}{l}\text { International Center for Agricultural Research } \\
\text { in Dry Areas (ICARDA) }\end{array}$ \\
\hline 34. & 29769 & PBW343/ETBW 4921//QAMAR-6 & $\begin{array}{l}\text { International Center for Agricultural Research } \\
\text { in Dry Areas (ICARDA) }\end{array}$ \\
\hline 35. & 29752 & PFAU/MILAN//ABIER-2/3/SHUHA-3//TURACO/CHIL & $\begin{array}{l}\text { International Center for Agricultural Research } \\
\text { in Dry Areas (ICARDA) }\end{array}$ \\
\hline 36. & 29858 & PFAU/MILAN//FLAG-3/3/NEJMAH-9 & $\begin{array}{l}\text { International Center for Agricultural Research } \\
\text { in Dry Areas (ICARDA) }\end{array}$ \\
\hline 37. & 29992 & QADANFER-4//ACHTAR/INRA 1764/3/SHAMISS-3 & $\begin{array}{l}\text { International Center for Agricultural Research } \\
\text { in Dry Areas (ICARDA) }\end{array}$ \\
\hline 38. & 30098 & RABIH-10/ETBW 4922//KAUZ'S'/FLORKWA-1 & $\begin{array}{l}\text { International Center for Agricultural Research } \\
\text { in Dry Areas (ICARDA) }\end{array}$ \\
\hline 39. & 29526 & RABIH-3/5/KAUZ/3/MYNA/VUL//BUC/FLK/4/MILAN & $\begin{array}{l}\text { International Center for Agricultural Research } \\
\text { in Dry Areas (ICARDA) }\end{array}$ \\
\hline 40. & 29945 & TEMPORALERA M 87*2/KONK//FAYEQ-1 & $\begin{array}{l}\text { International Center for Agricultural Research } \\
\text { in Dry Areas (ICARDA) }\end{array}$ \\
\hline 41. & 29988 & TEVEE'S'/SHUHA'S'//ACHTAR/INRA 1764/3/CHIL-1/SHUHA-1 & $\begin{array}{l}\text { International Center for Agricultural Research } \\
\text { in Dry Areas (ICARDA) }\end{array}$ \\
\hline 42. & 29903 & TRAP\#1/BOW//PFAU/3/MILAN/4/ETBW 4922/5/PFAU/MILAN & $\begin{array}{l}\text { International Center for Agricultural Research } \\
\text { in Dry Areas (ICARDA) }\end{array}$ \\
\hline 43. & 29812 & WATAN-6/ETBW 4919//ZAKIA-14 & $\begin{array}{l}\text { International Center for Agricultural Research } \\
\text { in Dry Areas (ICARDA) }\end{array}$ \\
\hline 44. & 29798 & WBLL1*2/BRAMBLING/3/OPATA/RAYON//KAUZ & $\begin{array}{l}\text { International Center for Agricultural Research } \\
\text { in Dry Areas (ICARDA) }\end{array}$ \\
\hline 45. & 29940 & WEAVER/TSC//WEAVER/3/WEAVER/4/WAXWING/5/DURRA-8 & $\begin{array}{l}\text { International Center for Agricultural Research } \\
\text { in Dry Areas (ICARDA) }\end{array}$ \\
\hline 46. & 29477 & WHEATEAR//ACHTAR/INRA 1764 & $\begin{array}{l}\text { International Center for Agricultural Research } \\
\text { in Dry Areas (ICARDA) }\end{array}$ \\
\hline 47. & 29476 & WHEATEAR//ACHTAR/INRA 1764 & $\begin{array}{l}\text { International Center for Agricultural Research } \\
\text { in Dry Areas (ICARDA) }\end{array}$ \\
\hline 48. & 29671 & ZAIN-4/QADANFER-11 & $\begin{array}{l}\text { International Center for Agricultural Research } \\
\text { in Dry Areas (ICARDA) }\end{array}$ \\
\hline 49. & 29913 & ZERBA-6/FLAG-6/3/TAM200/PASTOR//TOBA97 & $\begin{array}{l}\text { International Center for Agricultural Research } \\
\text { in Dry Areas (ICARDA) }\end{array}$ \\
\hline 50. & DBW107 (C) & DBW107 (C) & $\begin{array}{l}\text { AICRP-Indian Institute of Wheat and Barley } \\
\text { Research (ICAR-IIWBR) }\end{array}$ \\
\hline
\end{tabular}


The present investigation was conducted at 'AB' block farm BCKV (Bidhan Chandra Krishi Viswavidyalaya), Kalyani (22 $59^{\prime} \mathrm{N}, 88^{\circ} 48^{\prime} \mathrm{E}$, and $9.75 \mathrm{~m}$ above mean sea level) under the new alluvial zone of West Bengal, India during the Rabi season of two consecutive years 2018-2019 and 20192020. This area is primarily considered as hot spot area of spot blotch disease due to prevalent sub-tropical humid climatic condition with annual mean temperature range of $12.5^{\circ} \mathrm{C}-36.3^{\circ} \mathrm{C}$ and rainfall of $1120-1500 \mathrm{~mm}$ with relative humidity of $50-80 \%$, which is ideal for the development of disease. Fifty test genotypes were sown following randomized block design with three replications. In all the replications each genotype was planted in three rows of $3 \mathrm{~m}$ length keeping $18 \mathrm{~cm}$ distance between rows. The susceptible check Sonalika was included after every 20 test entries and along the borders to provide the chance of creating equal disease pressure to all the test genotypes. The sowing was done in the first week of December so that the post anthesis stage is exposed to warm and humid environment which is conducive for disease development (Chaurasia et al. 2000). During both the years, the crop was raised with recommended package of practices. A fertilizer dose of $120-60-40 \mathrm{~kg} / \mathrm{ha} \mathrm{N}-\mathrm{P}_{2} \mathrm{O}_{5}-\mathrm{K}_{2} \mathrm{O}$ was applied to the experimental plot. Half nitrogen and full amount of phosphorous and potassium was provided as basal during field preparation, a quarter of nitrogen was top dressed at 21 days after sowing (DAS) and another quarter at 40 DAS. Five irrigations were applied as recommended in the critical growth stages of the crop (crown root initiation stage, tillering stage, late jointing stage, flowering stage and dough stage) although the soil contained sufficient organic matter content $(0.78 \%)$ to retain moisture.

\section{Assessment of agro-morphological traits}

The agro-morphological traits assessed in this experiment were plant height (cm), days to $50 \%$ heading, days to $50 \%$ flowering, tillers per square meter, days to maturity, spike length (cm), grains per spike, test weight (g), yield/plant (g). Plant height was measured from the base at ground level to the tip of spike of main tiller excluding awns at maturity. Days to $50 \%$ heading and days to $50 \%$ flowering were counted as the number of days from sowing until $50 \%$ of the ear emerges fully from the boot of flag leaf and anthesis occurred in $50 \%$ of the ear in each plot respectively. Days to maturity were counted as the number of days from sowing till the grains became hard enough and contained moisture levels near $12 \%$. Test weight and yield/plant was recorded for each test genotype separately by taking weight in electric balance. Grains per spike were counted manually and panicle length was measured by a $30 \mathrm{~cm}$ long scale bar with $0.1 \mathrm{~cm}$ interval markings after harvest.

\section{Artificial inoculation of pathogen}

To impose an optimum disease pressure for thorough screening of test genotypes, artificial epiphytotic condition was created beside natural disease occurrence. A pure culture of aggressive Bipolaris sorokiniana isolate was obtained from Department of Plant Pathology, Bidhan Chandra Krishi Viswavidyalaya and maintained on potato dextrose agar (PDA) medium at $24 \pm 1^{\circ} \mathrm{C}$. For bulk propagation of spores, culture was multiplied on autoclaved sorghum (Sorghum bicolor L. Moench) grains for 20 days at $24 \pm 1^{\circ} \mathrm{C}$ under 12 hours alternate dark and light cycle (Duveiller and Altamirano 2000). The spore concentration in the suspension was kept roughly $10^{4} \mathrm{spores} / \mathrm{ml}$. The suspension was sprayed uniformly as a mist in the field using hand atomizer at three different growth stages (GS) of the crop on Zadoks scale (Zadoks et al. 1974), namely- tillering (GS20), flag leaf emergence (GS37) and anthesis (GS65) during evening hours. The field was irrigated immediately after inoculation to maintain a high level of moisture for successful disease development.

\section{Assessment of spot blotch disease reaction}

The spot blotch disease score was recorded using double digit scale (Singh and Kumar 2005) at three growth stages viz, GS73 (early milking), GS77 (late milking) and GS83 (soft dough) of Zadoks scale. The first digit and second digit of double-digit score represent the percent leaf area covered by spot blotch infection on the flag leaf and the penultimate leaf respectively. The disease severity percent of each genotype was estimated by following formula (Duveiller et al. 2005):

Disease severity \% $=(\mathrm{D} 1 / 9) \times(\mathrm{D} 2 / 9) / 100$

Where,

D1- first digit, refers to the vertical disease progress in accordance with the plant height

D2- second digit, refers to severity measured as the extent of diseased leaf area

To have an idea about the progress of disease with time, area under disease progress curve (AUDPC) based on disease severity score was calculated using the following expression (Das et al. 1992):

$A U D P C=\sum_{i=1}^{n-1}\left[\left\{\left(Y_{i}+Y_{(i+1)}\right) / 2\right\} \times\left(t_{(i+1)}-t_{i}\right)\right]$

$\mathrm{Yi}$ is the disease severity measured on the $\mathrm{i}^{\text {th }}$ date and $\left(\mathrm{t}_{(\mathrm{i}+1)}\right)^{\left.-\mathrm{t}_{\mathrm{i}}\right)}$ is the number of days in between two consecutive dates of disease scoring and $\mathrm{n}$ is the number of dates on which spot blotch was recorded.

Statistical analysis

Page 6/18 
The data obtained from the quantitative parameters of the 50 genotypes grown for two years were subjected to pooled analysis to consider the consistency of response of the test genotypes over the years. Analysis of variance (ANOVA) was performed for the characters under study. Estimates of genetic parameters like genotypic coefficient of variance (GCV) and phenotypic coefficient of variance (PCV) as per Burton (1952) and Burton and De Vane (1953), broad sense heritability $\left(\mathrm{h}^{2}\right)$ as per Hanson et al. (1956) and genetic advance as a percent of mean as per Johnson et al. (1955) were evaluated using the R-packages, version 3.6.1. Character association expressed in terms of correlation coefficient as per Al-Jiboari et al. (1958) and path coefficient analysis as suggested by Wright (1921) and discussed by Dewey and Lu (1959) were determined by Statistical Package for Agricultural Research (SPAR-I). Character with maximum influence on AUDPC was determined through multiple linear regression (MLR) using SPSS version 23.0. Genetic divergence among the genotypes was determined by the Mahalanobis' generalized distance (Mahalanobis 1936) as per Rao (1952) using Genres software version 7.01. Skewedness for AUDPC among the genotypes was calculated using SPSS version 23.0.

\section{Results}

Analysis of variance (Table 2) revealed significant differences among the fifty genotypes for all the ten quantitative characters. Heat map analysis (Fig. 1) arranged the genotypes and the characters into hierarchical clustering simultaneously based on similarity and distances between them and the pattern of colour mosaic indicated the association between the genotypes and the characters. High values (>20\%) of genotypic coefficient of variation (GCV) and phenotypic coefficient of variation (PCV) could not be recorded for any characters. However, among the characters the GCV and PCV values (Fig. 2) were highest for yield per plant followed by tillers per meter square and grains per spike. High heritability in broad sense (>60\%) was observed for all the characters excepting test weight, which was moderate $(51.50 \%)$. The characters like plant height and days to maturity showed high heritability but their genetic advance (Fig. 2) as percentage of mean was low (<10\%). The characters, tillers per square meter, grains per spike and yield per plant showed high heritability and high genetic advance as percent of mean. Very high heritability and moderate genetic advance was observed for days to $50 \%$ heading ( $94.50 \%$ and $14.43 \%$ respectively) and days to $50 \%$ flowering ( $91.60 \%$ and $12.11 \%$ respectively) Moderate heritability $(51.50 \%)$ and low genetic advance as percent of mean $(9.42 \%)$ was recorded for test weight.

Table 2

Analysis of variance for 9 quantitative characters including AUDPC of 50 wheat genotypes (pooled data of two years)

\begin{tabular}{|c|c|c|c|c|c|c|c|c|c|c|c|}
\hline $\begin{array}{l}\text { Sources } \\
\text { of } \\
\text { variation }\end{array}$ & $\begin{array}{l}\text { Degree } \\
\text { of } \\
\text { freedom }\end{array}$ & $\begin{array}{l}\text { Plant } \\
\text { height } \\
\text { (cm) }\end{array}$ & $\begin{array}{l}\text { Days to } \\
50 \% \\
\text { heading }\end{array}$ & $\begin{array}{l}\text { Days to } \\
50 \% \\
\text { flowering }\end{array}$ & Tillers/sq.m & $\begin{array}{l}\text { Days To } \\
\text { maturity }\end{array}$ & $\begin{array}{l}\text { Spike } \\
\text { length } \\
\text { (cm) }\end{array}$ & $\begin{array}{l}\text { Grains } \\
\text { per } \\
\text { spike }\end{array}$ & $\begin{array}{l}\text { Test } \\
\text { weight } \\
\text { (g) }\end{array}$ & $\begin{array}{l}\text { Yield/plant } \\
\text { (g) }\end{array}$ & $\begin{array}{l}\text { AUDPC } \\
\text { Score }\end{array}$ \\
\hline Genotype & 49 & $43.86 * *$ & $71.11 * \star$ & $64.24^{\star \star}$ & $210.32^{\star *}$ & $39.29 * \star$ & $1.53^{\star \star}$ & $80.90 * \star$ & $20.19 * \star$ & $1.86^{\star *}$ & $290442.4^{\text {** }}$ \\
\hline
\end{tabular}

For character association study using correlation analysis (Fig. 3a and 3b), area under disease progress curve (AUDPC) was taken into consideration to understand its interrelation with yield per plant and yield components. Yield per plant showed significantly negative correlation ( $0.323^{\star}$ and 0.280*) with AUDPC at both genotypic and phenotypic levels. Significant positive correlation with yield per plant at both genotypic and phenotypic levels were observed for days to $50 \%$ heading $\left(0.394^{\star \star}\right.$ and $\left.0.331^{\star}\right)$, days to $50 \%$ flowering $\left(0.383^{\star \star}\right.$ and $\left.0.319^{\star}\right)$, tillers per square meter $\left(0.530^{\star *}\right.$ and $\left.0.343^{\star}\right)$, spike length $\left(0.432^{\star *}\right.$ and $\left.0.449^{\star *}\right)$ and grains per spike $\left(0.884^{\star *}\right.$ and $\left.0.834^{\star *}\right)$. Days to maturity revealed significant positive correlation with yield per plant at only genotypic level and at phenotypic level although the correlation was positive it was not significant. Among the characters registering significant positive correlation with yield per plant, only days to $50 \%$ heading $\left(-0.493^{\star *}\right.$ and $\left.-0.464^{\star *}\right)$, days to $50 \%$ flowering $\left(-0.455^{\star *}\right.$ and $\left.-0.409^{\star *}\right)$, tillers per square meter $\left(-0.323^{*}\right.$ and $\left.0.281^{*}\right)$ and grains per spike revealed significant negative correlation with AUDPC at both genotypic and phenotypic level. Path coefficient analysis at both genotypic and phenotypic level (Fig. 4a and $4 \mathrm{~b})$ revealed that grains per spike had maximum direct positive effect on yield per plant ( 0.794 and 0.758 respectively) followed by days to $50 \%$ heading ( 0.080 and 0.041 respectively) and days to $50 \%$ flowering ( 0.079 and 0.040 respectively). The other characters having significant positive correlation with yield per plant had negative direct effect. The residual effect was low for both genotypic (0.02) and phenotypic (0.05) level. Multiple linear regression (Table 3 ) revealed days to $50 \%$ heading to be most sensitive towards AUDPC. The predictability (in terms of adjusted $\mathrm{R}^{2}$ ) of the MLR was highly significant being 0.661 .

Table 3

Multiple Linear Regression of quantitative characters on AUDPC score (Pooled data of two years

\begin{tabular}{|llll|}
\hline & $\mathbf{R}^{2}$ & Adj $\mathbf{R}^{2}$ & SE(est) \\
\hline AUDPC Score = 2883.350-30.867Days to 50\% heading & 0.698 & 0.661 & 275.27 \\
\hline
\end{tabular}

The genotypes could be grouped into 10 clusters (Table 4) based on $D^{2}$ square analysis. Cluster VI accommodated maximum genotypes (9), followed by cluster I accommodating 7 genotypes. Cluster II and cluster IX comprised of 6 genotypes each, while cluster X accommodated 5 genotypes and cluster VIII consisted of 3 genotypes while two genotypes grouped in cluster III and cluster IV, each. Maximum intra cluster distance was observed for cluster IV (9.23), followed by cluster VI (9.22), cluster X (8.93) and cluster I (8.26). The intra cluster distance of cluster II and cluster VI were also on a higher side being 7.29 and 7.91 respectively, while minimum intra cluster distance was recorded for cluster III (2.61) followed by 
cluster IV (2.73). Inter cluster distance was recorded to be maximum between cluster VII and cluster VIII (13.26), followed by cluster III and cluster V (12.03), cluster V and cluster VII (11.98) and cluster VIII and cluster X (11.68). Minimum inter cluster distance was registered between cluster II and cluster IV (6.53) followed by cluster II and cluster VII (7.86). Out of the 10 quantitative characters studied (Fig. 6), yield per plant contributed maximum (26.20\%) towards total divergence, followed by days to $50 \%$ heading $(23.92 \%)$, grains per spike ( $15.18 \%$ ) and days to $50 \%$ flowering (14.94\%). The contribution of plant height, tillers per square meter and spike length were not evident while the contribution of days to maturity and spike length were also less. The cluster mean analysis (Table 5) revealed the maximum cluster mean for days to $50 \%$ heading (73.00) and days to $50 \%$ flowering (78.78) in cluster VIII while cluster IV exhibited highest mean for grains per spike (50.17) and yield per plant (6.18g). Minimum cluster mean for days to $50 \%$ heading (61.56) and days to $50 \%$ flowering (69.50) were registered in cluster VII and minimum cluster mean for grains per spike (41.78) and yield (4.67) per plant were recorded in cluster VIII and cluster $V$ respectively.

Table-4. Clustering of the genotypes based on $D^{2}$ statistics (pooled data of two years)

\begin{tabular}{|c|c|c|c|c|c|c|c|c|c|}
\hline CLUSTER & GENOTYPES & & & & & & & & \\
\hline I & TERBOL & ATLAS & TESFA & 30140 & 30081 & 29782 & 29641 & & \\
\hline II & 29882 & 30053 & 29889 & 29760 & 29761 & 29784 & & & \\
\hline III & HD 2967 (C) & 29473 & & & & & & & \\
\hline IV & 29824 & 29858 & & & & & & & \\
\hline V & Sonalika (C) & 29872 & 29612 & 29703 & & & & & \\
\hline VI & 29610 & 29821 & 29690 & 29672 & 29748 & 29506 & 29509 & 29522 & 29798 \\
\hline VII & 29865 & 30001 & HD3086 (C) & 29502 & 29752 & 30098 & & & \\
\hline VIII & 29490 & 29477 & 29476 & & & & & & \\
\hline IX & 29769 & 29992 & 29526 & 29945 & 29988 & 29913 & & & \\
\hline$x$ & 29903 & 29812 & 29940 & 29671 & DBW107 (C) & & & & \\
\hline
\end{tabular}

Table 5

Cluster mean analysis (pooled data of two years)

\begin{tabular}{|c|c|c|c|c|c|c|c|c|c|}
\hline CLUSTER & $\begin{array}{l}\text { Plant } \\
\text { height } \\
\text { (cm) }\end{array}$ & $\begin{array}{l}\text { Days to } 50 \% \\
\text { heading }\end{array}$ & $\begin{array}{l}\text { Days to } 50 \% \\
\text { flowering }\end{array}$ & Tillers/sq.m & $\begin{array}{l}\text { Days To } \\
\text { maturity }\end{array}$ & $\begin{array}{l}\text { Spike } \\
\text { length } \\
\text { (cm) }\end{array}$ & $\begin{array}{l}\text { Grains } \\
\text { per spike }\end{array}$ & $\begin{array}{l}\text { Test } \\
\text { weight } \\
\text { (g) }\end{array}$ & $\begin{array}{l}\text { Yield/plant } \\
\text { (g) }\end{array}$ \\
\hline I & 90.78 & 66.05 & 73.10 & 64.76 & 96.91 & 9.25 & 45.29 & 35.07 & 5.29 \\
\hline ॥ & 94.66 & 69.56 & 77.44 & 75.06 & 97.39 & 9.14 & 47.67 & 36.72 & 5.82 \\
\hline III & 86.90 & 70.67 & 78.50 & 84.50 & 101.83 & 9.80 & 49.00 & 35.03 & 5.70 \\
\hline IV & 97.75 & 68.00 & 74.83 & 81.83 & 98.00 & 9.08 & 50.17 & 37.07 & 6.18 \\
\hline V & 95.94 & 63.00 & 70.67 & 68.58 & 95.75 & 8.22 & 40.83 & 34.51 & 4.67 \\
\hline VI & 95.05 & 68.59 & 75.96 & 71.59 & 98.59 & 9.02 & 42.70 & 35.16 & 5.00 \\
\hline VII & 92.48 & 61.56 & 69.50 & 70.78 & 96.00 & 9.38 & 44.28 & 35.37 & 5.17 \\
\hline VIII & 96.58 & 73.00 & 78.78 & 77.44 & 105.67 & 8.59 & 41.78 & 36.56 & 5.05 \\
\hline IX & 94.95 & 67.44 & 74.11 & 78.67 & 101.33 & 9.57 & 48.33 & 34.68 & 5.56 \\
\hline$x$ & 89.89 & 65.60 & 73.20 & 73.00 & 98.73 & 9.97 & 45.07 & 36.62 & 5.53 \\
\hline
\end{tabular}

Analysis of variance (Table 1) of the set of test genotypes not only depicted the variation for agro-morphological traits but also for their disease severity. Frequency distribution of AUDPC among the genotypes showed slight positive skewness (0.052) for the variable (Fig. 7) which was not statistically significant suggesting more or less normal distribution of the character. No genotype showed complete resistance (disease score 00 according to double digit score classification by Kumar et al. 2016) against Bipolaris sorokiniana. Lowest AUDPC value was recorded in genotype 29882 (245) followed by 29610 (250), 29473 (265), 29940 (410). The AUDPC value of the susceptible check variety Sonalika was very high (961.67). Two genotypes 29872 (1378.33) and 30001 (1375) showed higher AUDPC value than that of Sonalika. Low AUDPC score with acceptable level of 
yield performance (Fig. 8) with respect to the yield checks HD 2967, HD3086 and DBW 107 were recorded for the genotypes 29882, 29610, 29473, 29940, 29477, 29748 and 30081.

\section{Discussion}

Significant variation among the genotypes for all the quantitative characters was the testimony of varied parentage of the genotypes taken under study as suggested earlier by Arya et al. (2017a) and different agro-climatic conditions from where the genotypes were obtained (Yadav et al. 2014). Significant variation was further reflected by heat mapping, which not only hierarchically clustered the genotypes according to their distance and similarity but also simultaneously clustered the characters under study and revealed the interaction between the genotypes and characters. Hierarchical clustering is a powerful tool to agglomerate a group of individuals into a cluster based on their similarity and distance. Heat map consists of rectangular tiling, with each tile shaded on a colour scale to represent the value of the corresponding element of the data matrix and high and low values are depicted with complementary colour code (Wilkinson and Friendly 2009). Rectangular matrix of similar colour along the row helps to identify the traits that appear to be characteristic for corresponding genotype cluster. Phenotypic coefficient of variation (PCV) was greater than genotypic coefficient of variation (GCV) for all the characters suggesting environmental influence on the genotypes for the expression of the characters (Kumar et al. 2013; Hazra et al. 2019b). Low to moderate values of GCV and PCV were recorded for the characters similar to the findings of Poudel et al. (2021) and among all the characters, the highest values having been registered for yield per plant corroborated with the earlier reports (Arya et al. 2017a). Coefficient of variation for tillers per square meter and grains per spike was higher compared to the other characters which agreed well to earlier reports (Kumar et al. 2013; Yadav et al. 2014). Revelation of moderate variability for yield per plant, tillers per square meter and grains per spike suggested that there was still chance of improving these traits by selection while low variability for the other characters indicated that there was hardly any opportunity for genetic enhancement of these characters through selection (Mitra et al. 2020) and induction of variability by means of hybridization or mutation followed by selection can improve the traits (Poudel et al. 2021).

Heritability depicts the percentage of variability that is transmitted from parents to offspring. However, heritability alone cannot provide a reliable picture for genetic gain (Arya et al. 2017a; Sejake et al. 2020) as evident for characters like plant height and days to maturity which registered high heritability (broad sense) but low genetic advance as percent of mean. Combination of these genetic variability parameters indicated that these characters might not be governed by additive gene action hence, direct selection will not be effective. High heritability combined with high genetic advance reflects governing of the characters by additive genes thus, direct selection for those characters could be rewarding (Poudel et al. 2021). High heritability coupled with high genetic advance as percent of mean recorded for tillers per square meter, grains per spike and yield per plant suggested direct and early generation selection for these characters (Bhanu et al. 2018; Al-Nager et al. 2020). Days to 50\% heading and days to 50\% flowering registered very high heritability with moderate genetic advance as percent of mean indicating selection for these traits might be beneficial through their phenotypic performance (Hailu 2020; Poudel et al. 2021), while moderate heritability and low genetic advance as percent of mean for test weight suggested direct selection for this trait would be non-rewarding.

Selection based on yield alone, a complex character is generally not very effective. Correlation studies provide important information to identify and verify whether the selection for a certain character influences another one, to quantify indirect gains due to selection of correlated traits and to evaluate the complexity of the traits (Tiwari and Upadhyay 2011). Correlation coefficients for most of the characters at genotypic level were higher than the corresponding coefficients at phenotypic level indicating the presence of inherent genetic relationship among the characters as suggested earlier (Tripathi et al. 2015). Yield per plant registering significant negative correlation with AUDPC at both genotypic and phenotypic levels suggested that spot blotch disease was a major biotic constraint for realizing high yield in wheat as reported earlier (Meena et al. 2014; Ayana et al. 2018). Days to $50 \%$ heading, days to $50 \%$ flowering, tillers per square meter, spike length and grains per spike revealed significant positive correlation with yield per plant at both genotypic and phenotypic level. Days to maturity showed significant positive correlation at genotypic level but it was not significant at phenotypic level. This might be possible since the genetic advance as percent of mean for days to maturity was low indicating the character to be governed by non-additive genes and hence influenced by environment (Addisu and Shumet 2015; Hossain et al. 2021). The characters, days to $50 \%$ heading, days to $50 \%$ flowering, tillers per square meter and grains per spike revealed significant negative correlation with AUDPC at both genotypic and phenotypic level. The negative association between AUDPC and $50 \%$ days to heading and $50 \%$ days to flowering suggested a negative relation between the disease severity and duration of the crop (Mahto 2001; Sharma et al. 2006). Earlier reports also suggested negative correlation between disease severity and yield attributing parameters like, number of grains per spike and tillers per square meter (Gilchrist et al. 1991; Sharma et al. 1997; Sharma and Duveiller 2003, Singh et al. 2008). Non-significant correlation between AUDPC and plant height, spike length and test weight indicated a scope of simultaneous improvement of these traits and disease resistance. Selection of the characters having strong positive correlation with yield and simultaneous negative correlation with AUDPC would be rewarding in future wheat breeding programs (Sharma and Duveiller 2003). Correlation alone does not provide a clear picture of character association, since two characters might show correlation as a result of their correlation with a common third one (Poudel et al. 2021). Path coefficient analysis provides the actual information by splitting the correlation coefficients into measures of direct and indirect effects of the set of quantitative characters on yield per plant (Mecha et al. 2017). Grains per spike registered maximum direct positive effect on yield per plant at both genotypic and phenotypic level and its correlation with yield per plant was also very high. Days to $50 \%$ heading and days to $50 \%$ flowering also revealed positive direct effects although the values were very low. Other traits which had significant positive correlation with yield had negative direct effects. The low value of residual effect at both genotypic and phenotypic level suggested the inclusion of most of the responsible factors for grain yield per plant. AUDPC being complex and dependent on several factors, is difficult and often misleading to estimate empirically and data mining techniques in the form of MLR has been reported to be more accurate and is

Page 9/18 
becoming a new trend in understanding the sensitivity of several characters towards complex traits like AUDPC. (Nourani and Fard 2012). MLR extends linear modelling ideas to a wider class of response types, such as count data or binary responses (Sengupta et al. 2021) and is able to figure out the interrelationship among the input (Quantitative charaters) and the output data (AUDPC) and predict each output with its corresponding output. MLR analysis revealed days to $50 \%$ heading to be most sensitive towards AUDPC in a negative direction and the MLR equation suggested that the character contributed $66.1 \%$ towards AUDPC. Sensitivity analysis using MLR was in accordance with the findings of correlation study which indicated days to $50 \%$ heading to be negatively correlated with AUDPC. Correlation study along with MLR validated the character days to $50 \%$ heading to be most important for spot blotch resistance screening which might be due to the fact that in South East Asian countries the prevalence of spot blotch coincides with the heading and post-heading stage of wheat (Chowdhury et al. 2013). In this context it may be pointed out that breeding for short duration crops will be rewarding since reduction in days to $50 \%$ heading can alleviate the impact of spot blotch by escaping the critical stage (flowering).

The genotypes could be grouped into 10 clusters indicating presence of divergence among them. The clustering pattern suggested no parallelism between genetic diversity and geographical origin as recorded earlier in soybean, Glycine max L. (Malik et al. 2011) and tomato, Solanum lycopersicon L. (Debnath et al. 2020). Grouping of the genotypes of same geographical origin into different clusters might be due to change in certain characters as a result of natural or artificial selection (Narayan et al. 2018). The intra and inter cluster distance among the genotypes indicates the distance among the genotypes in a single cluster and between the genotypes of different cluster respectively. The intra and inter cluster $D^{2}$ distance depicted the diversity present within the genotypes in a particular cluster and among the clusters, respectively. Maximum intra cluster distance was recorded for cluster IV, while minimum was recorded for cluster III. High intra cluster distance suggested the genotypes within the cluster had high degree of divergence and would produce desirable breeding materials for attaining maximum genetic advance (Dobariya et al. 2006; Chandramohan et al. 2016) whereas low intra cluster distance suggests presence of homogeneity among the genotypes within the cluster and selection of genotypes within the cluster would be ineffective. High inter cluster distance was recorded between cluster VII and cluster VIII, cluster III and cluster V, cluster V and cluster VII and cluster VIII and cluster X. Higher inter cluster distance suggested that the genotypes grouped in these clusters revealed broad spectrum of genetic diversity and can be utilised in future wheat breeding program to isolate desirable transgressive segregates for developing potential high yielding wheat varieties (Singh et al. 2010; Arya et al. 2017b). Low inter cluster distance between cluster II and cluster IV and cluster II and cluster VII depicted close relationship between the genotypes present in the clusters. Yield per plant, days to $50 \%$ flowering, grains per spike and days to $50 \%$ heading contributed majorly towards total divergence. The characters contributing maximum towards divergence might offer good scope of improvement through selection (Anuradha et al. 2020; Kumar et al. 2020). From this context, the cluster mean analysis of the major contributing characters revealed maximum cluster mean for the days to $50 \%$ heading and days to $50 \%$ flowering were in in cluster VIII, while the minimum cluster mean for these characters were recorded in cluster IV. Maximum cluster mean for grains per spike and yield per plant were registered in cluster IV and minimum cluster mean for these characters were in cluster VIII and cluster V respectively. The contrasting value of cluster mean for the characters were evident from the high inter cluster distances between the clusters and inter crossing among the genotypes from these clusters might be rewarding.

The disease reaction of wheat genotypes was characterized by their response measured as area under disease progress curve (AUDPC) as suggested earlier by Duveiller et al. (1998) which significantly differed among the genotypes. Frequency distribution for AUDPC revealed more or less normal distribution suggesting that the variable was clustered more near the mean. This implied the presence of more number of moderately resistant/ moderately susceptible genotypes than that of highly susceptible or highly resistant ones. No genotypes showed complete resistance for the disease similar to the earlier reports on lack of resistance in the south Asian wheat cultivars by Siddique et al. (2006) and Sharma et al. (2006). AUDPC score of the susceptible check Sonalika was higher which was in accordance with earlier reports (Sharma et al. 2004; Sharma et al. 2006; Singh et al. 2007; Kumar et al. 2019). The genotypes 29872 and 30001 showing higher AUDPC value than Sonalika could be utilized as susceptible check variety only after screening their performance under high disease pressure in in-vitro and in-vivo conditions. Low AUDPC score along with acceptable level of yield performance with respect to the yield checks revealed by the genotypes 29882, 29610, 29473, 29940, 29477,29748 and 30081 provided an opportunity to be used as a variety as such or as promising parent in hybridization programme.

The present investigation screened the genotypes having low AUDPC score for spot blotch disease along with high yield under hot spot region which presented a reliable picture on the disease reaction of the genotypes. Moreover, the present study aimed at understanding the interaction of the genotypes with the quantitative characters through heat map analysis and also developing a selection criterion for screening better genotypes through identification of important yield attributing characters with negative correlation with AUDPC with further validation using multiple linear regression model. This kind of selection approach for screening high yielding resistant lines ensures great deal of novelty.

\section{Conclusion}

Breeding of high yielding and spot blotch resistance is of utmost importance in wheat especially in the South Asian countries like India. In the present investigation, the characters $50 \%$ days to flowering, $50 \%$ days to heading and grains per spike came out as the major yield attributing characters since they showed high heritability coupled with high genetic advance as percent of mean, significant positive correlation with yield per plant and simultaneous significant negative correlation with AUDPC and also conferring positive direct effect to yield per plant in path analysis. Multiple linear regression (MLR) identified days to $50 \%$ heading to be most sensitive towards AUDPC in a negative direction indicating breeding for short duration to be rewarding. $D^{2}$ analysis revealed presence of wide divergence among the genotypes by grouping them into ten clusters. Presence of superior

Page $10 / 18$ 
genotypes in different clusters of varied diversity broadens the scope of using them in combinational breeding programme to exploit transgressive segregates in positive direction. Among the 50 genotypes, 29882, 29610, 29473, 29940, 29477, 29748 and 30081 revealed acceptable yield performances with low AUDPC value. Identification of high yielding and less susceptible genotypes for spot blotch disease in the present investigation offered an opportunity for wheat improvement through selective breeding.

\section{Declarations}

\section{Acknowledgements}

We thank All India Coordinated Wheat and Barley Improvement Project (AICW\&BP), Bidhan Chandra KrishiViswavidyalaya, Kalyani, Nadia, West Bengal, India, for letting us use the field and provide necessary facilities for this investigation.

\section{Funding}

This research did not receive any specific grant from funding agencies in the public, commercial, or not-for-profit sectors.

\section{Declaration of Competing Interest}

The authors declare that they have no known competing financial interests or personal relationships that could have appeared to influence the work reported in this paper.

Availability of data and material: Not applicable

Code availability: Not applicable

\section{Authors' contributions}

All authors contributed significantly towards the final make-up of the paper.Conceptualisation (AnirbanMaji and Soham Hazra); Data curation (Soham Hazra, ShouvikGorai and Sudip Bhattacharya); Formal analysis (Pritam Roy, Shouvik Gorai and Sudip Bhattacharya); Investigation and methodology (Pritam Roy, MousumiMurmuand ShouvikGorai); Supervision (AnirbanMaji, Dhiman Mukherjee, andSubhra Mukherjee); Writing-original draft (Soham Hazra and ShouvikGorai); Writing-reviewing and editing (Anirban Maji).

\section{Ethical Approval:}

\section{Research involving Human Participants and/or Animals:}

This article does not contain any studies with human participants or animals performed by any of the authors.

\section{References}

1. Acharya K, Dutta AK, Pradhan P (2011) Bipolaris sorokiniana (Sacc.) Shoem.: The most destructive wheat fungal pathogen in the warmer areas. Aust J Crop Sci 5:1064-1071

2. Addisu A, Shumet T (2015) Variability, heritability and genetic advance for some yield and yield related traits in barley (Hordeum vulgare L.) landraces in Ethiopia. Int J Plant Breed Genet 9:68-76

3. Al-Jibouri HA, Miller PA, Robinson HF (1958) Genotypic and environmental variances and covariances in an upland Cotton cross of interspecific origin. Agron J 5:633-636

4. Al-Naggar AMM, El-Shafi MAEMA, El-Shal MH, Anany AH (2020) Selection criteria and selection environment for drought tolerance of Egyptian wheat (Triticum aestivum L.) landraces. Annu Res Rev Biol 35:25-40. https://doi.org/10.9734/arrb/2020/v35i230186

5. Anuradha B, Reddy PSKR, Sudini H, Geetha A (2020) Genetic divergence for yield and yield attributes in tomato (Solanum lycopersicum L.). Green Farming 11:293-298

6. Arya VK, Singh J, Kumar L, Kumar R, Kumar P, Chand P (2017a) Character association and path coefficient analysis in wheat (Triticum aestivum L.). Indian J Agric Res 51:245-251

7. Arya VK, Singh J, Kumar L, Kumar R, Kumar P, Chand P (2017b) Genetic variability and diversity analysis for yield and its components in wheat (Triticum aestivum L.). Indian J Agric Res 51:128-134

8. Ayana GT, Ali S, Sidhu JS, Gonzalez Hernandez JL, Turnipseed B, Sehgal SK (2018) Genome-wide association study for spot blotch resistance in hard winter wheat. Front Plant Sci 9:926. https://doi.org/10.3389/fpls.2018.00926

9. Baranwal DK, Mishra VK, Vishwakarma MK, Yadav PS, Arun B (2012) Studies on genetic variability, correlation and path analysis for yield and yield contributing traits in wheat (T. aestivum L. em Thell.). Plant Arch 12:99-104

10. Bhanu AN, Arun B, Mishara V (2018) Genetic variability, heritability and correlation study of physiological and yield traits in relation to heat tolerance in wheat (Triticum aestivum L.). BJSTR 2:2112-2116

Page $11 / 18$ 
11. Burton GW (1952) Quantitative inheritance in grasses. Proceeding 6th International Congress, Pennsylvania State College 1:277-283

12. Burton GW, De Vane E (1953) Estimating heritability in tall fescue (Festuca arundinacea). Agron J 45:478-481

13. Chand R, Pandey SP, Singh HV, Kumar S, Joshi AK (2003) Variability and its probable cause in natural populations of spot blotch pathogen Bipolaris sorokiniana of wheat (T. aestivum L.) in India. J Plant Dis Prot 110:27-35

14. Chandramohan Y, Srinivas B, Thippeswamy S, Padmaja D (2016) Diversity and variability analysis for yield parameters in rice (Oryza sativa L.) genotypes. Indian J Agric Res 50:609-613. http://dx.doi.org/10.18805/ijare.v0iOF.10777

15. Chaurasia S, Chand R, Joshi AK (2000) Relative dominance of Alternaria triticina Pras. et Prab and Bipolaris sorokiniana (Sacc.) Shoemaker in different growth stages of wheat (T. aestivum L.). J Plant Dis Prot 107:176-181

16. Chowdhury AK, Singh G, Tyagi BS, Ojha A, Dhar T, Bhattacharya PM (2013) Spot blotch disease of wheat-a new thrust area for sustaining productivity. J of Wheat res $5: 1-11$

17. Das MK, Rajaram S, Mundt CC, Kronstad WE (1992) Inheritance of slow-rusting resistance to leaf rust in wheat. Crop Sci 32:1452-1456

18. Debnath A, Kumar R, Prasad SK, Sharma N, Kushwah JK (2020) Multivariate analysis for genetic diversity estimation among tomato (Solanum lycopersicum L.) Genotypes. Ecol Environ Conserv 26:1208-1211

19. Dewey DR, Lu K (1959) A Correlation and Path-Coefficient Analysis of Components of Crested Wheat grass Seed Production. Agron J 51:515518. https://doi.org/10.2134/agronj1959.00021962005100090002x

20. Dobariya KL, Ribadia KH, Padhar PR, Ponkia HP (2006) Analysis of genetic divergence in some synthetic lines of bread wheat (Triticum aestivum L.). Advances in Plant Sciences 19:221-225

21. Duveiler E, Garcia Altamirano I (2000) Pathogenicity of Bipolaris sorokiniana isolates from wheat roots, leaves and grains in Mexico. Plant Pathol 49:235-242. https://doi.org/10.1046/j.1365-3059.2000.00443.x

22. Duveiller $E$ (2004) Controlling foliar blights of wheat in the rice-wheat systems of Asia. Plant Dis 88:552-556

23. Duveiller E, Kandel YR, Sharma RC, Shrestha SM (2005) Epidemiology of foliar blights (spot blotch and tan spot) of wheat in the plains bordering the Himalayas. Phytopathology 95:248-256

24. Duveiller E, Van Ginkel M, Dubin HJ (1998) Helminthosporium diseases of wheat: A summary of group discussions and recommendations. In: Duveiller E, Dubin HJ, Reeves J, McNab A (eds) Helminthosporium blights of wheat: spot Blotch and tan Spot. CIMMYT, Mexico, pp 1-5

25. Gilchrist LI, Pfeiffer WH, Velazquez C (1991) Resistance to Helminthosporium sativum in bread wheat: Relationship among infected plant parts and association with agronomic traits. In: Tanner DG, Mwangi W (eds) Seventh regional wheat workshop for Eastern, Central and Southern Africa. Nakuru, Kenya

26. Gupta A, Singh C, Kumar V, Kundu S, Tiwari V, Singh GP (2017) Indian wheat varieties at a glance. ICAR-Indian Institute of Wheat and Barley Research, Karnal pp 156

27. Gupta PK, Chand R, Vasistha NK, Pandey SP, Kumar U, Mishra VK, Joshi AK (2018) Spot blotch disease of wheat: the current status of research on genetics and breeding. Plant Pathol 67:508-531

28. Hailu F (2020) Genetic Variability, Heritability and Genetic Advance of Kabuli Chickpea (Cicer arietinum L.) for Agronomic Traits at Central Ethiopia. IJPBCS 7:710-714

29. Hanson CH, Robinson HF, Comstock RE (1956) Biometrical studies of yield in segregating populations of Korean lespedeza. Agron J 48:268272

30. Hazra S, Chaterjee S, Kumar VU, Mukherjee S, Maji A (2019b) Genetic variability and character association in late sown wheat genotypes. J Pharmacogn Phytochem 8:707-712

31. Hazra S, Chatterjee S, Kumar VU, Mukherjee S, Maji A (2019a) Multivariate analysis in bread wheat genotypes grown under late sown condition. Int J Chem Stud 7:2549-2552

32. Hossain MM, Azad MAK, Alam MS, Eaton TEJ (2021) Estimation of Variability, Heritability and Genetic Advance for Phenological, Physiological and Yield Contributing Attributes in Wheat Genotypes under Heat Stress Condition. Am J Plant Sci 12:586-602

33. Johnson HW, Robinson HF, Comstock RE (1955) Estimates of genetic and environmental variability in soybeans. Agron J 47:314-318

34. Joshi AK, Chand R, Arun B (2002) Relationship of plant height and days to maturity with resistance to spot blotch in wheat. Euphytica 123(2):221-228

35. Joshi AK, Ortiz-Ferrara G, Crossa J, Singh G, Alvarado G, Bhatta MR, Duveiller E, Sharma RC, Pandit DB, Siddique AB, Das SY, Sharma RN, Chand R (2007) Associations of Environments in South Asia Based on Spot Blotch Disease of Wheat Caused by Cochliobolus sativus. Crop Sci 47:1071-1081

36. Kumar A, Kumar M, Kumar V, Sharma VR, Chaudhary V (2020) Genetic Divergence Studies for Yield and Quality Traits in Okra [Abelmoschus esculentus (L.) Moench.]. Int J Agricult Stat Sci 16:355-360

37. Kumar R, Gaurav SS, Bhushan B, Pal R (2013) Study of genetic parameters andgenetic divergence for yield and yield components of bread wheat (Triticum aestivum L.). J of Wheat res 5:39-42 
38. Kumar S, Archak S, Tyagi RK, Kumar J, Vikas VK, Jacob SR, Srinivasan K, Radhamani J, Parimalan R, Sivaswamy M, Tyagi S, Yadav M, Kumari J, Deepali, Sharma S, Bhagat I, Meeta M, Bains NS, Chowdhury AK, Saha BC, Bhattacharya PM, Kumari J, Singh MC, Gangwar OP, Prasad P, Bharadwaj SC, Gogoi R, Sharma JB, GM SK, Saharan MS, Bag M, Roy A, Prasad TV, Sharma RK, Dutta M, Sharma I, Bansal KC (2016) Evaluation of 19,460 wheat accessions conserved in the Indian national genebank to identify new sources of resistance to rust and spot blotch diseases. PloS ONE 11:e0167702. https://doi.org/10.1371/journal.pone.0167702

39. Kumar U, Kumar S, Prasad R, Roder MS, Kumar S, Chand R, Mishra VK, Joshi AK (2019) Genetic gain on resistance to spot blotch of wheat by developing lines with near immunity. Crop Breed Genet Genom 1:e190017

40. Kumari N, Mehta VP, Bhatia JK (2020) Foodgrains Production in India: Trend and Decompositions Analysis. Econ Aff 65:333-342

41. Mahalanobis PC (1936) On the generalized distance in statistics. Proc National Institute of Science India 2:49-55

42. Mahto BN (2001) Effect of helminthosporium leaf blight on yield components and determination of resistance in selected wheat varieties. Ann Agric Res 22:177-181

43. Malik MFA, Ashraf M, Qureshi AS, Khan MR (2011) Investigation and comparison of some morphological traits of the soybean populations using cluster analysis. Pak J Bot 43:1249-1255

44. Mecha B, Alamerew S, Assefa A, Dutamo D, Assefa E (2017) Correlation and path coefficient studies of yield and yield associated traits in bread wheat (Triticum aestivum L.) genotypes. Adv Plants Agric Res 6:1-10

45. Meena N, Mishra VK, Baranwal DK, Singh AK, Rai VP, Prasad R, Arun B, Chand R (2014) Genetic evaluation of spring wheat (Triticum aestivum L.) recombinant inbred lines for spot blotch (Bipolaris Sorokiniana) resistance and yield components under natural conditions for South Asia. $\mathrm{J}$ Agric Sci Technol 16:1429-1440

46. Mitra M, Gantait S, Kundu R (2021) Genetic variability, character association and genetic divergence in groundnut (Arachis hypogaea L.) accessions. Legum Res 44:164-169

47. Narayan R, Mer MS, Singh DB, Jeena AS, Kishor A (2018) Genetic Divergence in Tomato (Solanum lycopersicum L.) Based on morpho-chemical traits under Polyhouse in Uttarakhand. Biotech Today: An International Journal of Biological Sciences 8(2):80-84

48. Nourani V, Fard MS (2012) Sensitivity analysis of the artificial neural network outputs in simulation of the evaporation process at different climatologic regimes. Adv Eng Softw 47:127-146

49. Poudel MR, Poudel PB, Puri RR, Paudel HK (2021) Variability, Correlation and Path Coefficient Analysis for Agro-morphological Traits in Wheat Genotypes (Triticum aestivum L.) under Normal and Heat Stress Conditions. Int J Appl Sci Biotechnol 9:65-74

50. Rao CR (1952) Advanced Statistical Methods in Biometrical Research. John Wiley and Sons, Inc., New York

51. Rehman A, Farooq M, Nawaz A, Al-Sadi AM, Al-Hashmi KS, Nadeem F, Ullah A (2018) Characterizing bread wheat genotypes of Pakistani origin for grain zinc biofortification potential. J Sci Food Agric 98:4824-4836

52. Rosyara UR, Duveiller E, Pant K, Sharma RC (2007) Variation in chlorophyll content, anatomical traits and agronomic performance of wheat genotypes differing in spot blotch resistance under natural epiphytotic conditions. Australas. Plant Pathol 36:245-251. https://doi.org/10.1071/AP07014

53. Sejake T, Shargie N, Christian R, Tsilo T (2020) Assessment of genetic diversity in sorghum germplasm using agro-morphological traits. South African Journal of Plant Soil 37:376-388. https://doi.org/10.1080/02571862.2020.1807628

54. Sengupta S, Bhattacharyya K, Mandal J, Bhattacharya P, Halder S, Pari A (2021) Deficit irrigation and organic amendments can reduce dietary arsenic risk from rice: introducing machine learning based prediction model from field data. Agric Ecosyst Environ 319:107516. https://doi.org/10.1016/j.agee.2021.107516

55. Shah AA, Kumar A, Kour A, Mondal SK (2020) Estimation of Heterosis for Yield Traits in F1 and F2 Generation of in Winter Wheat x Spring Wheat Cross Combinations (Triticum aestivum L.) under Rainfed Conditions. International Journal of Genetics 12(5):735-739

56. Sharma RC, Dubin HJ, Bhatta MR, Devkota RN (1997) Selection of spot blotch resistance in four spring wheat populations. Crop Sci 37:432-435

57. Sharma RC, Duveiller E (2003) Selection index for improving Helminthosporium leaf blight resistance, maturity and kernel weight in spring wheat. Crop Sci 43:2031-2036

58. Sharma RC, Duveiller E, Gyawali S, Shrestha SM, Chaudhary NK, Bhatta MR (2004) Resistance to Helminthosporium leaf blight and agronomic performance of spring wheat genotypes of diverse origins. Euphytica 139:33-44

59. Sharma RC, Pandey-Chhetri B, Duveiller E (2006) Heritability estimates of spot blotch resistance and its association with other traits in spring wheat crosses. Euphytica 147(3):317-327. https://doi.org/10.1007/s10681-005-9018-y

60. Siddique AB, Hossain MH, Duveiller E, Sharma RC (2006) Progress in wheat resistance to spotch blotch in Bangladesh. J Phytopathol 154:1622

61. Singh DP, Kumar P (2005) Method of scoring of leaf blight of wheat caused by Bipolaris sorokiniana (Sacc.) Shoem. at adult stage on top two leaves and its validation. In: eds. Sharma RC, Sharma JN (eds) Integrated Plant Disease Management, Scientific Publishers, India, pp 289-294

62. Singh G, Singh DP, Chatrath R, Tyagi BS, Singh GP, Singh SK, Shoran J (2007) Combating leaf blight in wheat through resistance breeding. Indian J Genet Plant Breed 67:293-296

Page $13 / 18$ 
63. Singh G, Tyagi BS, Singh GP, Chatrath R, Singh DP, Shoran J (2008) Genetic analysis and association of spot blotch resistance caused by Bipolaris sorokiniana with morphological and yield attributes in bread wheat (Triticum aestivum)

64. Indian J Agric Sci 78(11):957-961

65. Singh S, Mishra VK, Kharwar RN, Budhlakoti N, Ahirwar RN, Mishra DC, Kumar S, Chand R, Kumar U, Kumar S, Joshi AK (2020) Genetic characterization for lesion mimic and other traits in relation to spot blotch resistance in spring wheat. PloS ONE 15:e0240029. https://doi.org/10.1371/journal.pone.0240029

66. Singh SV, Tiwari LP, Sharma RK (2010) Genetic Variability, Correlation and Path analysis in bread wheat (Triticum aestivum L.). Indian J of Genet 6:91-93

67. Singh V, Singh G, Chaudhury A, Ojha A, Tyagi BS, Chowdhary AK, Sheoran S (2016) Phenotyping at hot spots and tagging of QTLs conferring spot blotch resistance in bread wheat. Mol Biol Rep 43:1293-1303

68. Tiwari JK, Upadhyay D (2011) Correlation and path-coefficient studies in tomato (Lycopersicon esculentum Mill.). Res J Agric Sci 2:63-68

69. Tripathi GP, Parde NS, Zate DK, Lal GM (2015) Geneticvariability and heritability studies on bread wheat (Triticum aestivum L.). Int J Plant Sci 10:57-59

70. Turan R, Tyagi BS, Sharma A, Singh G, Singh V, Ojha A (2017) Assessment of genetic variability and correlation among agro-morphological traits and spot blotch disease in a RIL population of wheat. J Wheat Res 9(2):108-114

71. USDA (2021) National Agricultural Statistics Service Report, USDA. https://www.nass.usda.gov

72. Wilkinson L, Friendly M (2009) The history of the cluster heat map. Am Stat 63:179-184

73. Wright S (1921) Systems of mating. I. The biometric relations between parent and offspring. Genetics 6:111-123

74. Yadav SK, Singh AK, Baghel SS, Jarman M, Singh AK (2014) Assessment of genetic variability and diversity for yield and its contributing traits among CIMMYT based wheat germplasm. J Wheat Res 6:154-159

75. Zadoks JC, Chang TT, Konzak CF (1974) A decimal code for the growth stages of cereals. Weed Res 14:415-421

\section{Figures}

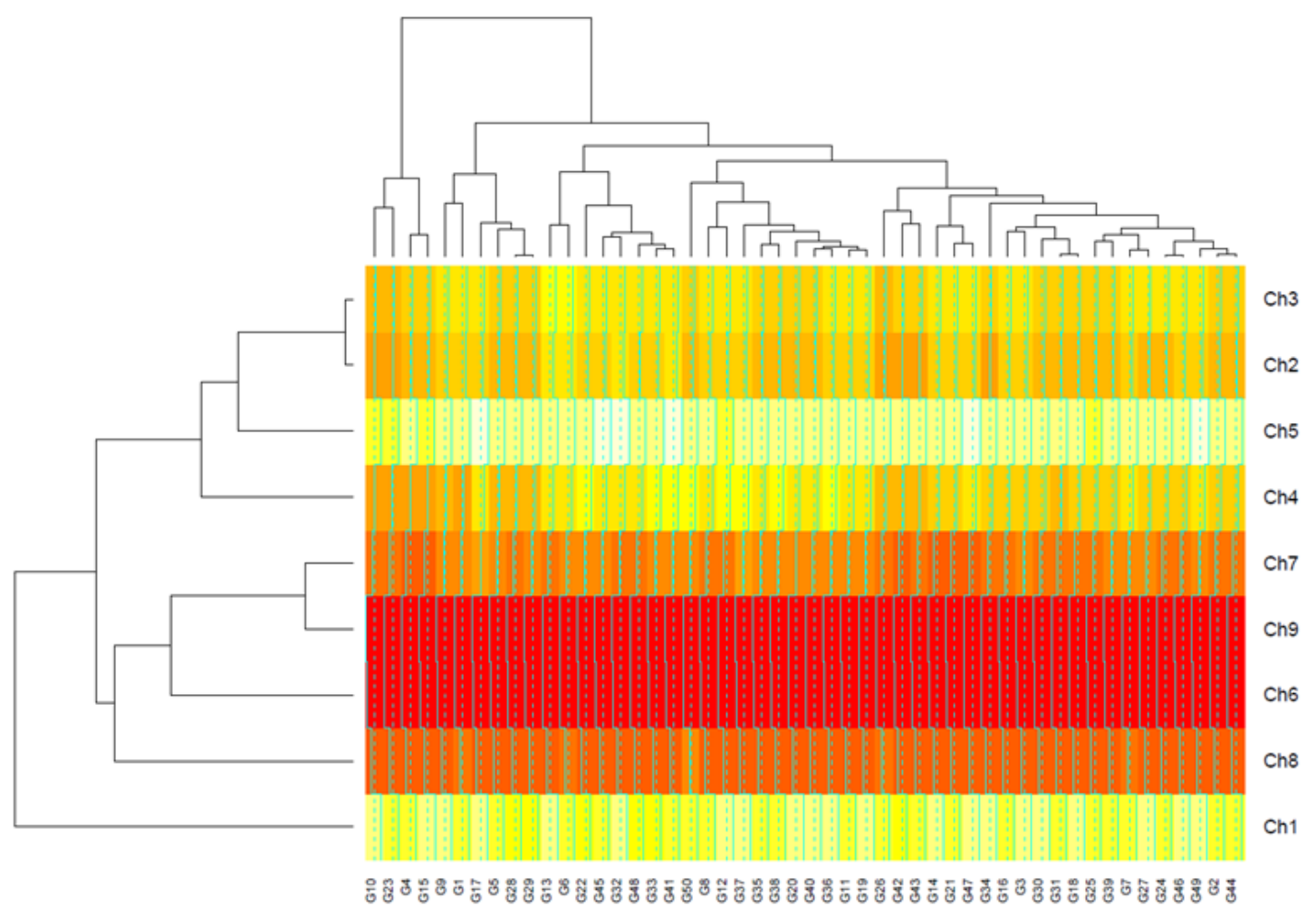

\section{Figure 1}

Heat map clustering analysis of 50 genotypes across 9 characters. The rows of a microarray heat map represent characters, and the columns represent the genotypes. Each cell is colorized based on the level of expression of that character in that sample Here, $\mathrm{G}$ represents genotype followed by numerical as described in Table 1 and Ch represents characters as plant height (Ch1), days to $50 \%$ heading (Ch2), days to 50\% flowering (Ch3), Tillers/sq.m (Ch4), Days To maturity (Ch5), Spike length (Ch6), Grains per spike (Ch7), Test weight (Ch8), and yield/plant (Ch9) 


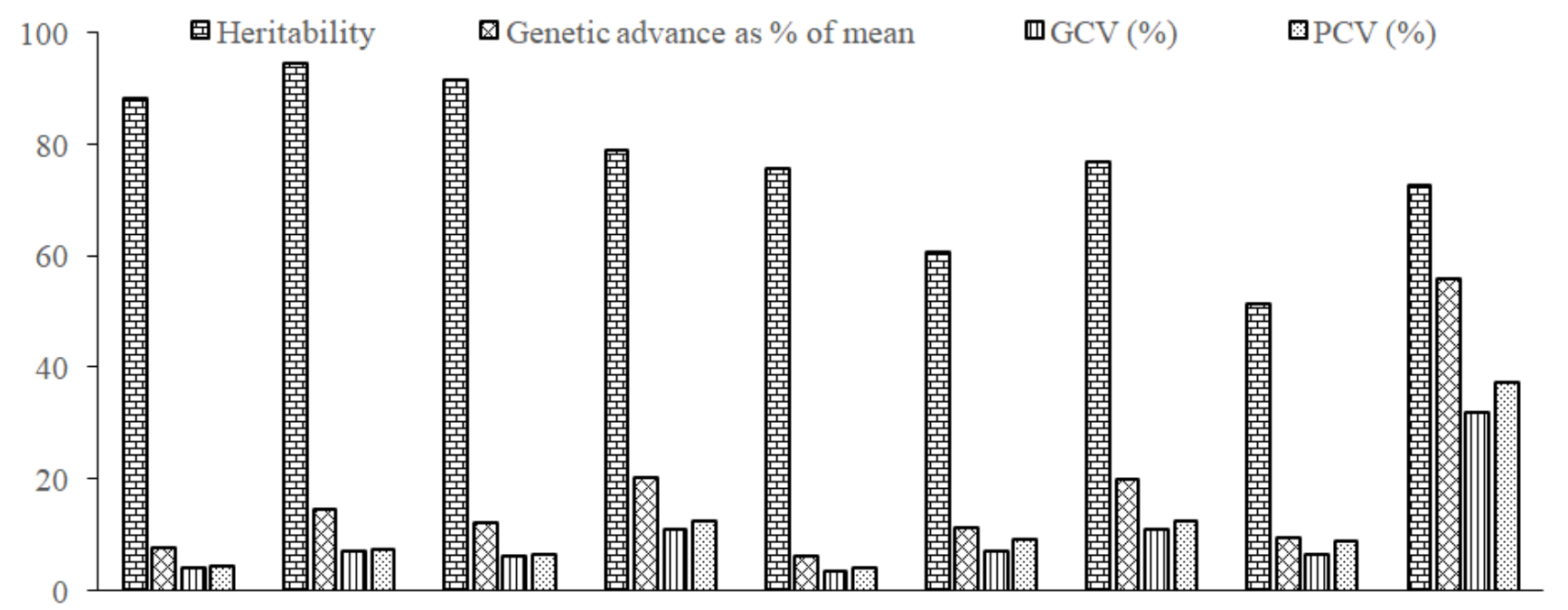



\section{Figure 2}

GCV, PCV, Heritability (broad sense), Genetic advance as percent of mean of the nine quantitative characters (pooled data of two years)
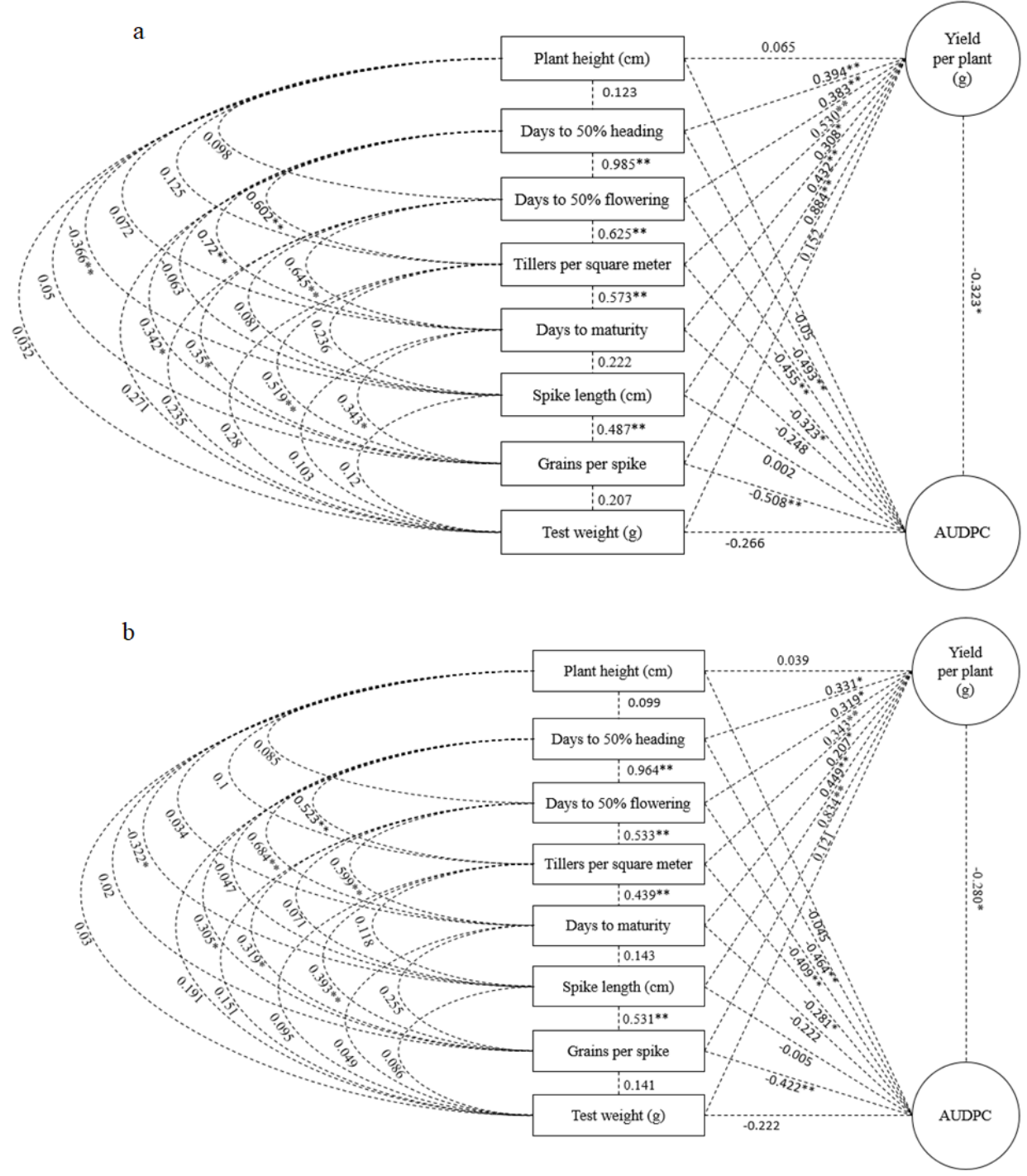

Figure 3 
a. Genotypic correlation of yield, and yield contributing traits including AUDPC (pooled data of two years). Significance levels are provided by * (5\%) and $* \star(1 \%)$ respectively. b. Phenotypic correlation of yield, and yield contributing traits including AUDPC (pooled data of two years). Significance levels are provided by * $(5 \%)$ and ** $(1 \%)$ respectively.
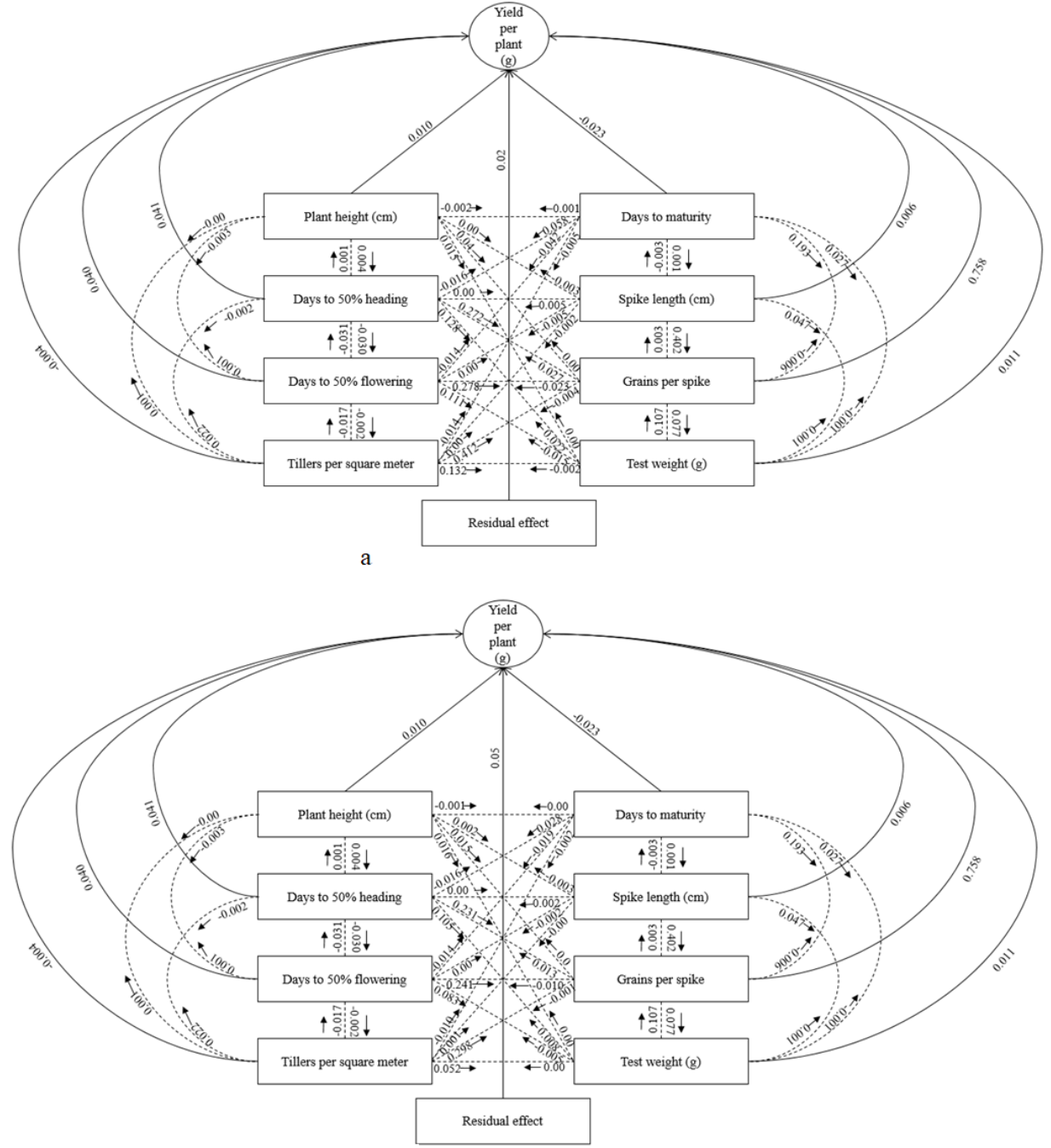

b

\section{Figure 4}

a. Genotypic path coefficient analysis indicating direct and indirect effects of the independent variables over yield (solid line represents direct effect, while dotted line refers to indirect effects, and the arrow signifies the relatable variables; as pooled data of two years). b. Phenotypic path coefficient analysis indicating direct and indirect effects of the independent variables over yield (solid line represents direct effect, while dotted line refers to indirect effects, and the arrow signifies the relatable variables; as pooled data of two years). 


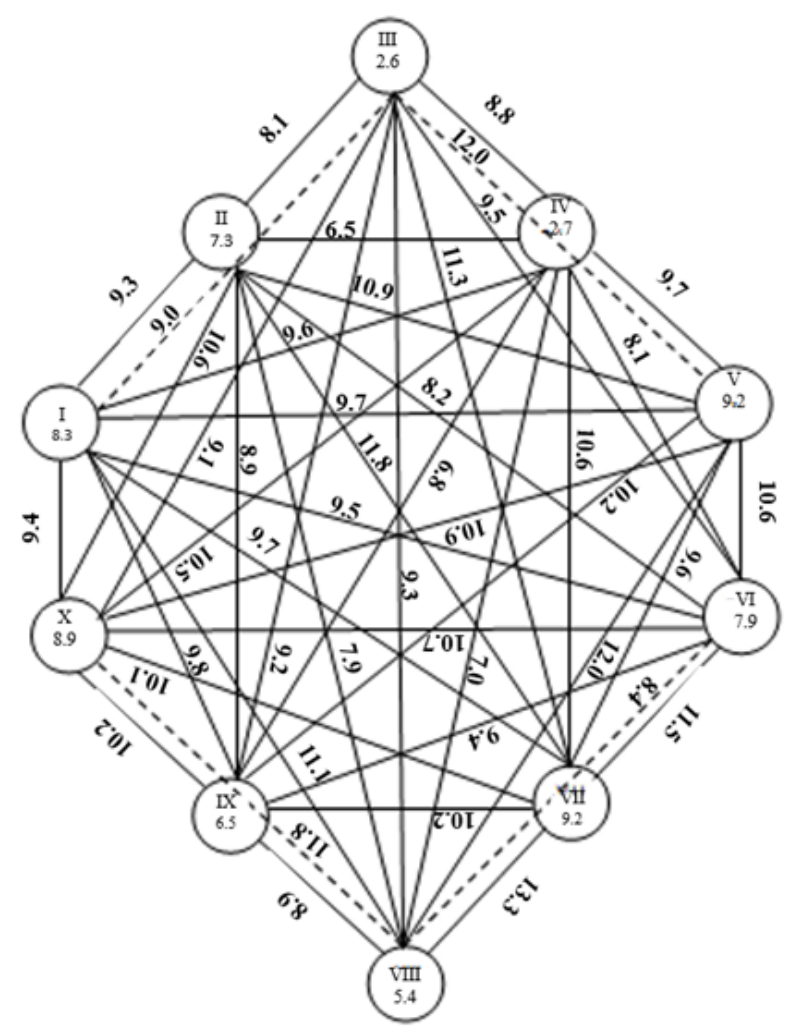

Figure 5

Inter cluster and intra cluster distance of the genotypes (not to scale); (pooled data of two years)

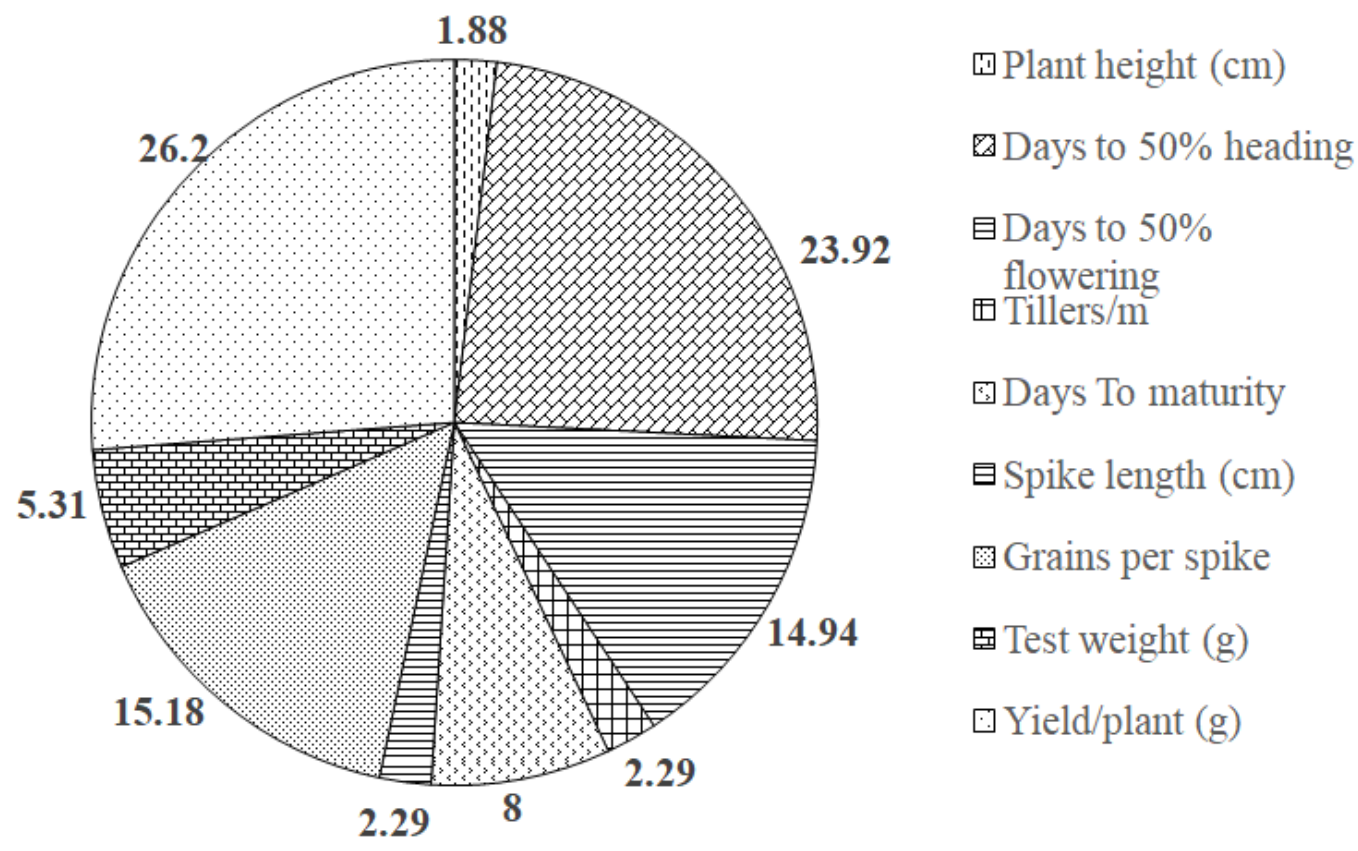

Figure 6

Percentage contribution of the characters towards divergence(pooled data of two years) 


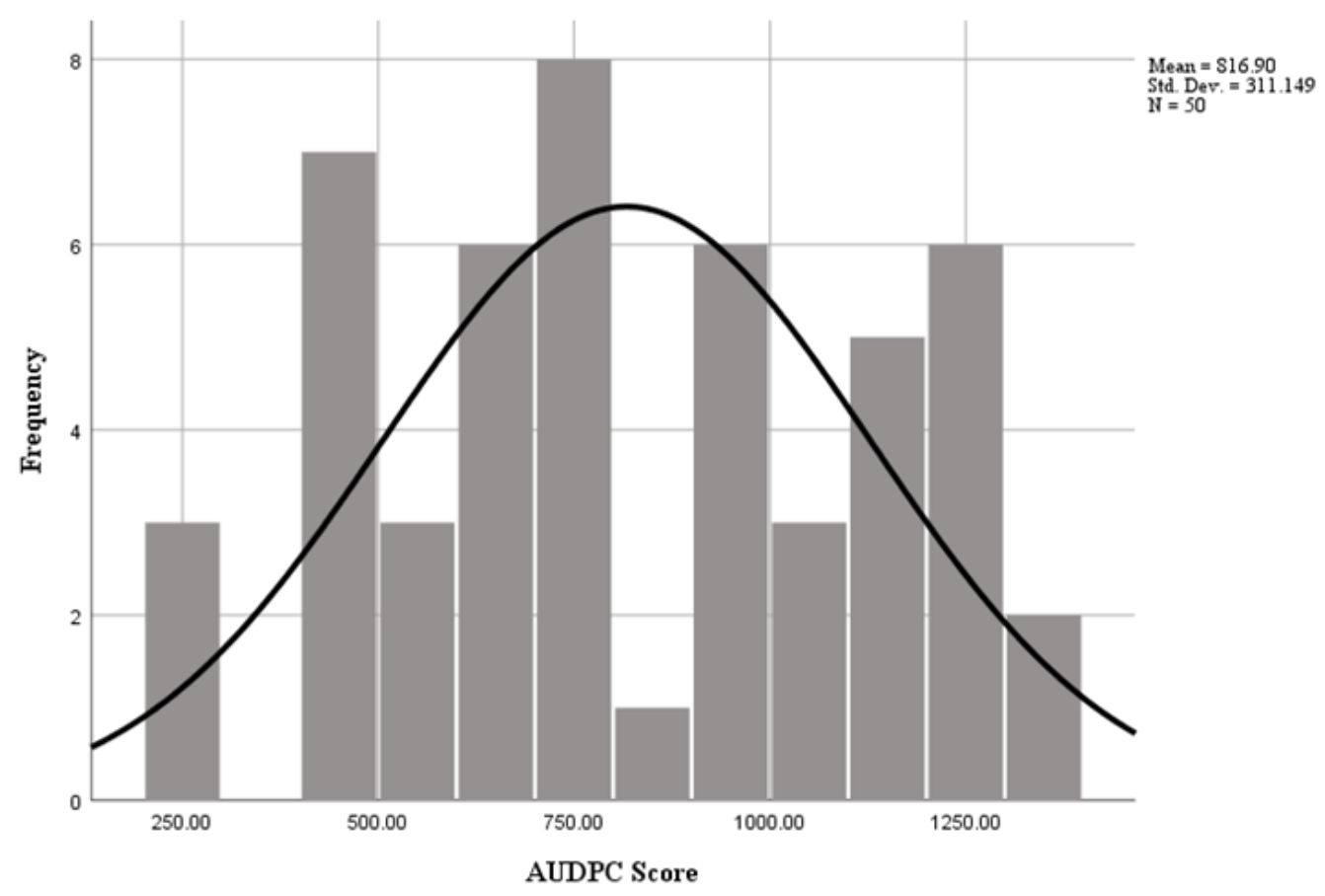

\section{Figure 7}

Frequency distribution of AUDPC among the genotypes(pooled data of two years)



Figure 8

Yield per plot and AUDPC score of the selected genotypes as compared to the check varieties (pooled data of two years). 